\title{
Approaching the PIDE 'From Below': Petitions, Spontaneous Applications and Denunciation Letters to Salazar's Secret Police in 1964
}

\author{
Duncan Simpson \\ Instituto de Ciências Sociais (ICS) da Universidade de Lisboa, Av. Professor Aníbal de Bettencourt 9, Lisbon 1600-189, \\ Portugal. \\ duncan.simpson@ics.ulisboa.pt
}

\begin{abstract}
Under the Salazar regime, many Portuguese citizens spontaneously interacted with the secret police (PIDE), sending it letters of denunciation, prospective applications and petitions. The historians of the Estado Novo, by reducing the nature of the relations between the PIDE and society to its mechanisms of top-down repression, have overlooked the significance of the phenomenon. Drawing on the inputs of the international bibliography on accusatory practices and 'everyday life' under dictatorship, this article looks at the PIDE through the subjective perspectives of the individual citizens who approached it 'from below', thereby nuancing and complementing the established narrative of violence and repression. It focuses on the instrumentalisation of the PIDE by ordinary citizens as: an influential sponsor; an appropriable device of coercion; an instrument of private conflict resolution; a platform for collaborative interaction with the regime; an economic opportunity. The article also puts forward an interpretation of these 'everyday' interactions as part of a broader system of governance used by the authorities of the New State.
\end{abstract}

\section{Introduction}

On 24 August 1964 Sub-inspector António Augusto Teodósio, of the Salazarist secret police (Polícia Internacional e de Defesa do Estado; PIDE), sent his superiors in Lisbon a report on the social and political situation in Guarda, a medium-sized town in the north of Portugal. 'From every corner of the region', he wrote, 'we are receiving anonymous letters, telephone calls and other indications informing us of the constant flight [abroad] of individual [citizens], mostly young men evading military service'. ${ }^{1}$ His purpose was to alert the higher authorities of the magnitude of the task facing the PIDE in its mission to contain illegal emigration. Indirectly, the content of the report also provided emphatic evidence of the importance of spontaneous denunciations as a social phenomenon in António de Oliveira Salazar's Estado Novo, or New State, established in 1933. Already in 1951 Joaquim Trigo de Negreiros, the Minister of the Interior responsible for the secret police, had felt compelled to deplore the influx of denunciation letters sent to him by members of the public. ${ }^{2}$ These reports challenged the regime's claims to a harmonious society, and suggest the existence of patterns of denunciation across Portugal under the Salazar dictatorship.

The PIDE, to which most of these letters were sent, was created in October 1945 as part of the New State's institutional makeover designed to adjust the regime to the Allied victory. Its predecessor, the Polícia de Vigilância e de Defesa do Estado (PVDE), had been too closely associated with memories of the 'fascist era'. In practice, however, the PIDE maintained most of the PVDE's extensive arbitrary powers in its threefold mission to ensure the 'security of the State' (by eliminating all forms of political

\footnotetext{
1 Portuguese National Archives (ANTT), PIDE, SC, SR 1330/64, NT3403, 3.

2 Irene Flunser Pimentel, A História da PIDE (Rio de Mouro: Círculo de Leitores, 2007), 74. 
dissent), control the national borders and act as an intelligence agency. In the aftermath of the Second Word War, the PIDE focused on those sectors of the opposition bolstered by the Allied victory, such as 'old' republicans and communists. From the second half of the 1950s it also increasingly had to face a rapidly increasing flow of illegal emigration and the multiplication of oppositionist initiatives, including by 'progressive' Catholics and radical far-left groups. The outbreak of the colonial war in 1961 and concomitant deployment of PIDE agents overseas contributed to stretching its resources further by the mid-1960s. ${ }^{3}$

The fact that the PIDE, as a political police, attracted denunciations from unsolicited citizens was not particular to the Salazar dictatorship. In the cases of Soviet Russia and East Germany, research carried out by Sheila Fitzpatrick and Robert Gellately has shown the prevalence of the phenomenon, ${ }^{4}$ to the point that officials often became weary of a practice considered contrary to the ideal of a socialist society and unreliable for police work. ${ }^{5}$ Yet whilst this phenomenon of 'accusatory practices ${ }^{6}$ has been examined in a range of European countries and contexts, it has been largely overlooked by historians of the New State, as have been other forms of bottom-up interactions between society and the PIDE. While some scholars have sought to unravel the intricacies of the PIDE's operation on the ground such as the effect of recalcitrant local elites ${ }^{7}$ or internal conflicts between police entities ${ }^{8}-$ and to relativise the regime's use of violence by setting it in comparative perspective, ${ }^{9}$ the main scholarly works devoted exclusively to the PIDE have continued to focus overwhelmingly on processes of top-down repression as the only form of relation between society and the political police. Consequently the historiography of the subject area remains defined by its strong emphasis on such aspects as the persecution of oppositionists through arbitrary internment and torture, and the PIDE's influence as a fear-inducing deterrent on the rest of the population, reduced to the role of 'passive victims' ${ }^{10}$

This article aims to restore society to a more active role in its relations with the regime's repressive apparatus by looking at the PIDE 'from below', that is, from the subjective perspectives of the individual citizens who spontaneously interacted with it. The analysis focuses on the year 1964, chosen as the starting point in a broader research programme aimed at exploring the relations between society and the PIDE in the final decade of the regime. It is based on a collection of letters gathered in the context of an exploratory foray into the PIDE Archives, the correspondence registers of the ministry of the Interior and the Archives of the Presidency of the Council, held at the Portuguese National Archives. Letters written by unsolicited citizens are extremely hard to come by, since they are scattered amongst the multitude of PIDE case files and across different archival collections. Using rigorous

\footnotetext{
3 For an introductory overview of the Salazarist secret police, see Irene Flunser Pimentel, 'A Polícia Política do Estado Novo Português, PIDE/DGS: História, Justiça e Memória', Acervo, 24, 1 (2011), 139-56.

4 Sheila Fitzpatrick, 'Supplicants and Citizens: Public Letter-Writing in Soviet Russia in the 1930', Slavic Review, 55, 1 (1996), 78-105.

5 Robert Gellately, 'Denunciations in Twentieth Century Germany: Aspects of Self-Policing in the Third Reich and the German Democratic Republic', Journal of Modern History, 68 (1996), 957-8.

6 Robert Gellately and Sheila Fitzpatrick, eds., Accusatory Practices: Denunciation in Modern European History, 1789-1989 (Chicago: University of Chicago Press, 1997).

7 Alexander Keese and Beatriz Valverde Contreras, 'The Limits of Authoritarian Rule at the Periphery: The PIDE, the American Airbase, and Social Control on Terceira Island, Azores, 1954-1962', Journal of Social History, 52, 4 (2019), 1307-29.

8 Victor Pereira, La Dictature de Salazar face à l'Émigration: l'État Portugais et ses Migrants en France (1957-1974) (Paris: Presses de Science Po, 2012) and 'El Poder de la Impotencia : Policías y Migración Clandestina entre Portugal y Francia (1957-1974)’, Política y Sociedad, 42, 3 (2005), 103-20.

9 Rui Ramos, ed., História de Portugal (Lisbon: Esfera dos Livros, 2009), 650-3; Diego Palacios Cerezales, Portugal à Coronhada (Lisbon: Tinta-da-China, 2011), 293.

10 See Maria da Conceição Ribeiro, A Polícia Política no Estado Novo 1926-1945 (Lisbon: Editorial Estampa, 1995); João Madeira, ed., Vítimas de Salazar: Estado Novo e Violência Política (Lisbon: Esfera dos Livros, 2007); Pimentel, História da PIDE; Fernando Rosas et al., Tribunais Políticos: Tribunais Militares Especiais e Tribunais Plenários durante a Ditadura e o Estado Novo (Lisbon: Temas e Debates, 2009); Fernando Rosas, Salazar e o Poder (Lisbon: Tinta-da-China, 2012), 190-210; Irene Flunser Pimentel, Os Cinco Pilares da PIDE (Lisbon: Esfera dos Livros, 2019).
} 
methods to trace this kind of correspondence, ${ }^{11}$ it was possible to locate twenty-eight letters of denunciation. ${ }^{12}$ References to a further fifty-six such letters were found in the correspondence registers of the Ministry of the Interior, which include a brief summary of their content. ${ }^{13}$ Eighty-one letters of 'spontaneous applications' by individual citizens wanting to join the PIDE were also found in the Ministry of the Interior's registers. One particular case of petitioning a PIDE official by the members of a small community on the outskirts of Lisbon was found in the Archives of the Presidency of the Council. ${ }^{14}$ Despite being a relatively small body of sources, it is possible to draw conclusions from these letters, files and cases which allow us to uncover new aspects of the relation between society and the PIDE.

By integrating these various forms of bottom-up relations between individual citizens and the PIDE, and by drawing on a broad historiography of denunciatory practices and historians of 'everyday life', this article aims to reveal the multiple kinds of interactions that existed between individual citizens and the PIDE. It argues that these 'everyday' interactions must be taken into consideration in order to reach a more complete understanding of the mechanisms that contributed to the exceptional durability of the regime, thereby nuancing and complementing the established historiographical narrative of repression and violence. ${ }^{15}$ On the one hand, these interactions must be understood as part of the New State's 'capillary operation of power', ${ }^{16}$ frequently allowing Salazarist authority to stretch into the smallest and most private aspects of life. On the other, they show how ordinary citizens willingly engaged with the PIDE, instrumentalising it to fulfil personal agendas or satisfy basic necessities. The history of relations between society and the secret police was not merely one of political repression; it was also part of a larger, European-wide issue of day-to-day survival for ordinary citizens forced to live under - and adapt to - unresponsive systems of dictatorial rule.

The article is structured around the five ways in which the secret police was instrumentalised by the population in Salazarist Portugal: as an influential sponsor, as an appropriable device of coercion, as an instrument of private conflict resolution, as a platform for collaborative interaction and as an economic opportunity. I shall consider each of these collaborations in succession. Crucially, the patterns which emerge belong to a wider web of behaviours across European societies and dictatorships. Comparisons with contemporaneous authoritarian experiences are laced throughout the article and underlined in the conclusion, in order to situate the specificities of the Salazarist secret police within this broader international perspective. In the conclusion, the collection of letters will also be used to suggest an interpretation of the relevance of 'everyday' interactions between individual citizens and the

11 The methods consisted of reading through as many of the individual case files currently open to researchers for 1964 as was possible during the research period (a total of seventy-eight files out of an available 143, ranging in length from a few pages to several hundred, were consulted in this way) and surveying the correspondence registers of the ministry of the Interior and the catalogue of the Archives of the Presidency of the Council, making use of its (relatively) precise content descriptions to request the more 'promising' documents.

12 PIDE, Del. P., PC 154/64, NT3211, 4; PIDE, Del. P., PC 44/64, NT3204; PIDE, Del. P., PC 44/64, NT3204, 28-29; PIDE, Del. P., PC 44/64, NT3204, 30-31; PIDE, SC, PC 904/64, NT5642, 50; PIDE, SC, PC 1728/64, NT5691, 24; PIDE, Del. C., Proc. s/nº, NT10713, 77-78; PIDE-SC/E/GT649, NT1444, 8; PIDE-SC/E/GT649, NT1444, 10; PIDE, Del. C., Proc. 553, NT10690; PIDE, Del. P., P. Ind. 34531, NT3985 ; PIDE, Del P., P. Ind 34659, NT 3987; PIDE, Del P., P. Ind. 34598, NT3986; PIDE, Del P., P. Ind 15159, NT3690; PIDE, Del P., P. Ind. 30967, NT3932; PIDE, Del P.,P. Ind. 33018, NT3961; PIDE, Del. P., P. Ind. 34172, NT3979; PIDE, Del. P., P. Ind 34460, NT3984; PIDE, Del. P., P. Ind. 4040, NT3529; PIDE, Del. P., P. Ind. 10502, NT3618; PIDE, Del. P., P. Ind. 34015, NT3977; PIDE, Del. P., P. Ind. 18962, NT3755; PIDE, Del. P., P. Ind. 16358, NT3710; PIDE, Del. P., P. Ind. 34494, NT3985; PCOS/MC, PRC11/B-8-4, NT152; PCOS/MC, PRC11/A-44-4, NT151; PCOS/MC, PRC3/B-85-6, NT120; PCOS/MC, PRC11/B-3-9, NT152.

13 ANTT, Ministério do Interior, Gabinete do Ministro (inc. 2003), Registo de Correspondência Recebida, 1964, NT34-3536.

14 PCOS/MC, PRC11/A-30-7, NT149.

15 As such this article builds upon my recently published study, Duncan Simpson, 'The "Sad Grandmother", the "Simple but Honest Portuguese" and the "Good Son of the Fatherland": Letters of Denunciation in the Final Decade of the Salazar Regime', Análise Social, 226 (2018), 6-27. Based on a PIDE file containing letters of denunciation written during the final decade of the regime, it centres on establishing a typology of denunciations in Salazar's Portugal and on highlighting the contribution of self-policing to the accomplishment of the PIDE's mission.

16 Michel Foucault, Surveiller et Punir (Paris: Gallimard, 1975), 231. 
PIDE as part of a broader system of exercising power in the Salazar regime. In particular, the widespread use of discretionary decision making by the agents of authority, ultimately as a means of enticing the population into collaboration with the regime to address their daily needs, suggests that the New State's model of power shared important similarities with clientelism as a system of social control. According to this system, subaltern social groups could benefit from a multitude of dispensed 'favours' in return for their submission to the regime.

\section{The PIDE as Influential Sponsor}

The New State originated from the wave of dictatorships born of the interwar crisis of parliamentary liberalism, embodied in Portugal by the financial and political instability of the First Republic (191026). The regime was formally instituted through the constitution of 1933 as an assemblage of the various currents of the anti-liberal right under the leadership of Salazar, a former militant of the Portuguese Catholic Centre. In ideological terms it is best defined as a form of conservative authoritarianism in which nationalism and 'traditional' social and moral values - carried essentially by the Catholic Church - were taken as references for the process of national 'regeneration'. Despite a brief fascist surge within the regime between 1936 and 1940, resulting from the context of civil war in neighbouring Spain, the New State thereafter remained a regime of low-intensity ideological mobilisation, combined with a purposeful thrust towards the political demobilisation of the people. 'Politics' remained the preserve of a chosen elite, whilst paramilitary organisations such as the Portuguese Youth were downgraded to 'sporting associations'. ${ }^{17}$

Salazar's able management of the politics of neutrality meant that the regime survived the Second World War. It then benefited from Cold War geopolitics to further entrench its position as a conservative, anti-communist partner in the Western coalition of the 1950s. In spite of rising domestic contestation - best illustrated by the popular support generated during the 1958 presidential election by the candidate of the opposition, General Humberto Delgado - the regime had recovered much of its internal stability by 1964 . The national context was by then marked by the colonial war and its consequences. ${ }^{18}$ Socially and economically Portugal was in the midst of a momentous transformative process. Partly in response to the backward state of the economy that had fed popular discontent in 1958, the regime had launched a process of modernisation which saw the structure of the economy alter profoundly. In 1963 the value of industrial production exceeded that of agricultural production for the first time ever. Investment in the economy, education and social support schemes also increased, leading to a general improvement in living conditions. ${ }^{19}$

The effects of this general trend towards economic amelioration should not be overstated, however. Not only was the modernisation process affected by deep regional asymmetries - making Portugal the 'dualist society' as described by sociologist Adérito Sedas Nunes in $1964^{20}$ - but, in 1970 the rural population still accounted for 32 per cent of the active population. With agriculture incapable of satisfying urban food consumption preferences ${ }^{21}$ and grave shortcomings in the electricity network, public water supply and basic road infrastructures, everyday life remained a struggle. Even in the expanding urban centres, the 'fragilities' remained 'great'. ${ }^{22}$ These social divisions were highlighted in November 1967 when over 500 people died in the floods that hit Lisbon, the majority from the

\footnotetext{
17 The best synthesis on the New State and twentieth-century Portugal more generally in the English language remains António Costa Pinto, ed., Contemporary Portugal: Politics, Society and Culture (New York: Columbia University Press, 2011 [2nd ed.]), 45.

18 The regime's obstinate refusal to adapt to the 'wind of change' eventually led to war with the African liberation movements in Angola (Mar. 1961), Guinea (Jan. 1963) and Mozambique (Sept. 1964). The conflict ended only in the aftermath of the revolution of 25 April 1974 that toppled the Salazar regime in metropolitan Portugal.

19 Ramos, ed., História de Portugal, 687 and 689-90.

20 Adérito Sedas Nunes, 'Portugal, Sociedade Dualista em Evolução', Análise Social, 7-8 (1964), 407-62.

21 Luciano Amaral, 'Portugal e o Passado: Política Agrária, Grupos de Pressão e Evolução da Agricultura Portuguesa Durante o Estado Novo (1950-1973)', Análise Social, 128 (1994), 889-906.

22 Ramos, ed., História de Portugal, 690.
} 
poor neighbourhoods on the outskirts of the capital. ${ }^{23}$ So economic modernisation aside, Portugal in the mid-1960s remained a deeply unequal society, with few opportunities for social ascension or economic betterment for large segments of the population. The 1.5 million migrants who opted to leave the country between 1957 and $1974^{24}$ provided the clearest expression of this.

In addition to dire economic prospects, the population faced an unresponsive political system, which not only excluded them from the decision making process (and from the discussion of 'politics' altogether) but also submitted them to an unpredictable bureaucracy, conceived as an instrument of social control. As Joyce Riegelhaupt has shown in her study of apoliticism in 1960s rural Portugal, the New State 'eliminated the municipality as an arena for discussion, debate and power of decision on subjects of public administration and the distribution of powers', and 'in its place . . created a highly centralised bureaucratic administration'. In this system 'the peasants were dependent on the central power; for them', she concluded, 'politics consisted in looking for an influence that would facilitate the execution of a plan of action'. ${ }^{25}$ The existence of clientelistic networks run by rural notables and landowners, in particular in the north and centre of the country, is well known. In return for their servility, the small peasantry depended on them not just as a source of complementary income but as a point of access to the (few) benefits offered by the central state. ${ }^{26}$ On a practical level, endemic poverty meant that the wealthy and influential were often approached as potential sponsors, in the hope of obtaining from them some form of support be it access to land, to a working position or to the concession of credit.

One case study shows that within the context of the 'clientelistic society' the PIDE itself figured among the institutions whose representatives could be mobilised 'from below' in the hope of superseding the obstacles of political and social non-inclusiveness. The case took place in A-da-Beja, a small semi-rural locality in the municipality of Belas, on the outer fringes of Greater Lisbon. It involved a PIDE official, António Faria Pais. ${ }^{27}$ As he explained in a report to his superiors in February 1964, 'because I started renting a country house [in A-da-Beja] in the middle of last year, they [the local inhabitants] now see me as someone capable of helping them'. 'For that reason', he continued, 'they constantly ask me for support'. ${ }^{28}$ The object of their petitioning, in the present case, was the installing of public street lighting in the municipality, which the local authorities had previously committed themselves to but thus far had failed to implement. The locals who petitioned Faria Pais assumed that he would be able to support them either by exerting his own influence or by activating his personal contacts with the authorities above him. He did the latter. On 7 February 1964 he wrote a letter to the influential former sub-director of the PIDE, Agostinho Barbieri Cardoso, ${ }^{29}$ reminding him of 'the promise made by His Excellency the minister of Public Works to these poor people, who for being poor . . . require superior patronage'. Faria Pais hoped that Barbieri Cardoso would in turn activate 'his good offices' with the sub-secretary of State for Industry, ${ }^{30}$ which he

${ }^{23}$ For a good, albeit journalistic treatment of the event, see https://www.publico.pt/2017/11/12/sociedade/reportagem/anoite-do-fim-do-mundo-1791985 (last visited 23 Jan. 2020).

24 Pereira, La Dictature de Salazar Face à l'Émigration, 11.

25 Joyce F. Riegelhaupt, 'Os Camponeses e a Política no Portugal de Salazar: O Estado Corporativo e o "Apoliticismo” nas Aldeias', Análise Social, 59 (1976), 510.

26 Manuel Carlos Silva, 'Camponeses Nortenhos: “Conservadorismo” ou Estratégias de Sobrevivência, Mobilidade e Resistência?', Análise Social, 97 (1987), 437-45.

27 Faria Pais had joined the PVDE in 1944 and transited to the PIDE in 1945. In 1948 he was appointed head of the PIDE's General Services. Simultaneously he integrated the PIDE's Administrative Council, until his retirement in 1964, at the age of seventy, in Irene Flunser Pimentel, O Caso da PIDE/DGS (Lisbon: Temas e Debates, 2017), 628.

28 PCOS/MC, PRC11/A-30-7, NT149, 7 Feb. 1964, 4.

29 In 1964 Barbieri Cardoso's position as 'inspector-superior' did not reflect his true influence in the PIDE. After joining the secret police in April 1948 he was appointed in 1950 to Salazar's personal security services. From this position he developed a close relation with the dictator, frequently addressing personal letters to him. He held the position of sub-director of the PIDE between May 1958 and December 1960, when he resigned out of a personal disagreement with the newly appointed director, Homero de Matos. Following the latter's replacement by Fernando Silva Pais, he re-joined the PIDE in April 1962, and was appointed sub-director in October 1972, in Pimentel, O Caso da PIDE/DGS, 611-2.

30 PCOS/MC, PRC11/A-30-7, NT149, 7 Feb. 1964, 4. 
did. A copy of António Faria Pais's original letter also reached the presidency of the council, possibly as a result of Barbieri Cardoso's personal relations with Salazar. The case came to a close a few weeks later, when Faria Pais received a letter from the secretariat of State for Industry ensuring him that his request 'would be attended to in the current year'. ${ }^{31}$

The case file does not make it clear whether the locals who petitioned Faria Pais knew that he was a PIDE official. They might have approached him simply because he looked (in his appearance and lifestyle) like a person of influence. It is perfectly plausible, however, that his position was known locally. The PIDE entertained no secrecy over its personnel, ${ }^{32}$ and the local community in any case benefited from informal informational channels, at the inter-individual level, that could easily have provided it with the essential information about the new resident. It is therefore possible that Faria Pais was approached, at least in part, because he represented an institution widely perceived at the time to carry significant clout within the regime, making him a particularly valuable sponsor in the eyes of the local population.

The phenomenon has been observed in other dictatorial settings, particularly in the case of highlongevity regimes whose secret police had time to sink deeper roots in society. In East Germany it was the Stasi's reputation for omnipotence which meant that individual citizens called upon it for even the most basic of purposes, such as obtaining 'urgently needed roof tiles for decrepit buildings' or even 'spare parts for idle production lines'. ${ }^{33}$ Notwithstanding the differences in social contexts and ideological dynamics, in each of these cases the secret police's perceived power and capabilities meant it was being approached by individual citizens who believed it could help them to overcome the obstacles posed by an unresponsive political system.

Unfortunately, the archives contained no other cases similar to this one; however, the fact that Faria Pais introduced his letter to Barbieri Cardoso as 'yet another request' indicated that this was not the first time he had acted as an intermediary between ordinary people and the higher authorities in the regime. The swiftness with which the problem was addressed - i.e. the pledge by the Secretariat of State for Industry to attend the situation 'in the current year' - also suggested a sense of normalcy in the procedure, and that this type of occurrence was not infrequent.

\section{The PIDE as Appropriable Device of Coercion}

If the influence of the PIDE within the regime contributed to making it a valuable sponsor in the eyes of the population, in other situations individual citizens approached the PIDE in the hope of benefiting from its coercive powers. Their aim was to appropriate the PIDE's fear-inducing potential. ${ }^{34}$ Historians of 'everyday life' have studied how ordinary citizens sought to adapt intrusive forms of governance to individual and family advantage, emphasising crime and fraud as one of the simpler adaptive practices. Richard J. Bosworth and Sheila Fitzpatrick have shown how under Mussolini and Stalin, respectively, conmen were able to manipulate their relation with the secret police for material gain. ${ }^{35}$

31 PCOS/MC, PRC11/A-30-7, NT149, Apr. 1964, 1.

32 Irene Flunser Pimentel, Biografia de um Inspector da PIDE: Fernando Gouveia e o Partido Communista Português (Lisbon: Esfera dos Livros, 2008), 240.

33 Jens Gieseke, The History of the Stasi: East Germany's Secret Police, 1945-1990 (Oxford: Berghahn Books, 2014 ), 111.

34 Fear of the PIDE, commonly presented as an all-pervasive social force in Salazar's Portugal (although no research has been carried out specifically on the theme), is partly discernible in the sample. The anonymous factory worker from Porto who, on 28 March 1964, wrote a letter to the PIDE to denounce a work colleague - allegedly engaged in protests 'against the Government' -, explained that he did so 'because [he] want[ed] to protect [him] self and [his] other colleagues' from the potential repressive measures of the political police, PIDE, Del. P., P. Ind.34659, NT3987, 3. Among the authors who have emphasised coercion over consent as the dominant factor in the construction of dictatorial power, see, on the German case, Peter Lambert, 'The Third Reich: Police State or Self-Policing Society?', in Alf Lüdtke, ed., Everyday Life in Mass Dictatorship: Collusion and Evasion (New York: Palgrave Macmillan, 2016), 37-54 and Richard J. Evans, 'Coercion and Consent in Nazi Germany', Raleigh Lecture on History, Proceedings of the British Academy, 151 (2007), 53-81.

35 On the role of 'tricksters' in Stalin's Soviet Russia, see Sheila Fitzpatrick, Everyday Stalinism (Oxford: Oxford University Press, 1999), and 'The World of Ostap Bender: Soviet Confidence Men in the Stalin Period', Slavic Review, 61 (2002), 535- 
Frauds usually consisted in a citizen (falsely) claiming some form of association with the regime (such as by alleging a role in the secret police or simply using the threat posed by its existence) as a means of enhancing their own importance and achieving some kind of material gain. This phenomenon existed in Salazar's Portugal too.

One case in the archives involved a Lisbon-based publishing house, the Organizações Império, when one of its representatives, José de Oliveira, tried to use the PIDE's reputation in order to coerce members of the public into buying one of its books. Entitled Thirty Years of New State (Trinta Anos de Estado Novo), the book, published in 1958, was essentially an illustrated propaganda work, highlighting the successes of the regime in facilitating the economic and moral 'revival' of the nation. As part of his commercial strategy José de Oliveira sent out copies of it to potential buyers, such as booksellers, lawyers' offices and shop owners across the country. If they chose not to purchase it, they were expected to send the copy back to him. When, in June 1961, the director of a law firm in Porto ('A. Raposo e Morais') refused to acknowledge receipt of the book, José de Oliveira sent him a menacing letter, in which he not only criticised his attitude but threatened to bring it 'to the attention of certain Official Organisms, so that it be known what Your Excellency thinks of a work that is at the service of PORTUGAL (and of all right-minded Portuguese) $\left[\right.$ sic] ${ }^{36}$ Upon receiving this letter the lawyer in turn wrote to the PIDE to complain about the publisher, in particular his 'willingness to misrepresent the "Official Organisms" referred to in the letter', which he took as a thinly-veiled reference to the secret police (in effect defending it as an institution). Several local shopkeepers, he indicated, were equally 'repelled' by the stratagem. ${ }^{37}$ The PIDE agreed with them. In his report the agent responsible for the case described the publisher's methods as a form of 'blackmail' and José de Oliveira as an 'opportunist' who needed to be 'restrained in his manoeuvres'. ${ }^{38}$ Whatever measures were taken by the PIDE proved insufficient. In 1964 José de Oliveira again informed the PIDE that another one of his customers had not only refused to return his copy of Thirty Years of New State, but had joked about using it 'to make confetti'. ${ }^{39}$ According to the final report on the case, dated 7 February 1964, a formal investigation into José de Oliveira's behaviour was launched due to his repeated attempt 'to coerce those to whom the books are sent into buying them under threat of reporting them to [the PIDE]'. ${ }^{40}$ The final result of the investigation is not known.

Opportunistic fraudsters were not the only ones to see the PIDE as an appropriable instrument of coercion. Under certain circumstances would-be emigrants approached the PIDE for similar purposes. Of the twenty-four denunciation letters relating to clandestine emigration, three were sent to the PIDE by discontented migrants following a failed attempt to cross the border. In them they denounced to the secret police the 'recruiters of migrants' (engajadores) and 'people smugglers' (passadores) whose services they had hired to operate their passage abroad. The typical denunciation was triggered by some form of wrongdoing (sometimes perceived, but usually real) on the part of the latter, and some denunciations were made even before the attempt to cross the border had begun. On 21 April 1964 Firmino de Barros and Manuel da Silva were arrested by the PIDE in Porto for 'fraud in the context of the recruitment of migrants', after one of their clients, António Martins, denounced them for failing to provide him with a (duly paid for) passport. ${ }^{41}$ Others denounced their passadores to the PIDE if they thought that the quality of the 'service' provided by them had been unsatisfactory during the journey - a complex process involving a series of interconnected clandestine networks from Portugal to France or Germany. On 31 March 1964 Alfredo Pereira, from Vizela, wrote to the PIDE to denounce his passador, Mário Brás, because he felt 'deceived' by him, having been arrested

57. On fraudsters in fascist Italy, see Richard J. B. Bosworth, Mussolini's Italy: Life under the Fascist dictatorship 1915-1945 (London: Penguin Books, 2006), 317-8.

36 PIDE, Del. P., P. Ind. 4040, NT3529, June 1961, 9.

37 PIDE, Del. P., P. Ind. 4040, NT3529, 17 June 1961, 8.

38 PIDE, Del. P., P. Ind. 4040, NT3529, 19 June 1964, 6.

39 PIDE, Del. P., P. Ind. 4040, NT3529, 4 Feb. 1964, 3.

40 PIDE, Del. P., P. Ind. 4040, NT3529, 2.

41 PIDE, SC, PC 299/64, NT5604, 7-8; and PIDE, Del P, PC 57/64, NT3205, 1-2. 
by the police upon arrival in France and sent back to Portugal. As one understands by the content of his letter, he also hoped that the PIDE would help him to recover the money he had paid in advance. ${ }^{42}$

What is particularly striking about these cases is the fact that contacting the PIDE was being resorted to by illegal migrants in the hope of solving a problem that was itself a crime that fell under the secret police's jurisdiction. ${ }^{43}$ By reporting these occurrences to the PIDE the migrants effectively put themselves at risk of being arrested too. That they did so can nevertheless possibly be explained by the fact that they were aware of the PIDE's structural inability to deal with the scale of the phenomenon of clandestine emigration. Indeed, by 1964 the PIDE lacked not only the manpower to patrol the borders efficiently but also the logistical means needed to arrest the increasingly large number of illegal emigrants and transport them to the detention centres. ${ }^{44}$ From experience, personal or indirect, the migrants expected lenient treatment from the PIDE - and, more widely, from the equally overburdened judicial apparatus. ${ }^{45}$ The secret police's targets were not the migrants themselves but the engajadores and passadores whose actions kept the clandestine networks flowing.

The denunciation letters provide a very original insight into the migrants' perception of the PIDE. Naturally they resented, and sometimes feared, the PIDE as the police force ultimately responsible for preventing their exit from the country. But the letters, which usually included an appeal for some kind of 'assistance' from the PIDE, also showed how easily they could bring themselves to consider the PIDE as a 'legitimate' police entity - on a par with the regular police forces - if it suited them. The PIDE's much asserted negative public image was apparently insufficiently strong to dissuade them from doing so. Fundamentally, the denunciation letters were also part of the complex economy of relations between the migrants and the people smugglers. The threat posed by the PIDE was being appropriated by the migrants as part of a purposeful strategy to assert a degree of control over the smugglers. Smugglers were also well aware of the risk posed by their clients who, not without reason, they branded 'the contraband that speaks'. ${ }^{46}$

The instrumentalisation of the PIDE as a device of control or punishment was one of the rare means by which the migrants could break out of a position of passivity and dependence. On 29 August 1964 Fernando Alves, an illegal migrant whose journey to France had been particularly difficult, wrote to his mother to ask her to report the identity of his passador first to the local Guarda Nacional Republicana (GNR) post and then, if 'they show no interest [in the case]', to the captain of the GNR in Braga. 'And let me know what happens', he insisted, 'since I have a letter ready to send to the PIDE, because he [the people smuggler] told me I would have to walk [only] six hours and that I would not go hungry, and it was the worst situation I ever experienced I never felt so hungry and walked so much, for 40 hours [sic]'. ${ }^{47}$ The case showed that for humble rural dwellers (sociologically, the overwhelming majority of the migrants) the PIDE could also be perceived as a superior, more reliable police entity capable of overcoming not only locally established interests but also the (not infrequent) corruption of the GNR guards operating near the border.

The growing sense of impunity among the illegal migrants and their relatives fostered a new set of perceptions in relation to the PIDE, focusing less on its (increasingly reduced) capacity for effective repression and more on the instrumental uses that could be made of it in the context of their attempts to emigrate. In a letter to the secret police dated 21 August 1964, one worried parent, Maria Nascimento, even called upon the PIDE to 'seek information on the whereabouts of [her] son Rui Ferreira and his wife' after she failed to receive any news from them in the aftermath of their

\footnotetext{
42 PIDE, Del. P., PC 44/64, NT3204, 4.

43 Between April 1961 (Decree Law 43528) and November 1969 (during the 'Marcellist Spring'), illegal emigration was considered a crime, punishable by two years in prison. Prior to that, it had been a fine-incurring offence.

44 Pereira, 'El Poder de la Impotencia', 111.

45 After 1963 the PIDE no longer investigated cases of clandestine emigration. The arrested migrants were released after interrogation, subject to statement of identity and residence, Pimentel, História da PIDE, 70.

46 Under interrogation, many of the migrants arrested whilst crossing the border also had no qualms about denouncing their engajadores and passadores to the PIDE.

47 PIDE, Del. P., PC 242/64, NT3221, 29 Aug. 1964, 12.
} 
departure. ${ }^{48}$ Decades later, after the downfall of the regime, a former PIDE agent, Oscar Cardoso, claimed that 'many wives and mothers of migrants' came 'to our headquarters to ask for help in visiting their husbands and sons abroad'. They 'resorted to us', he observed, 'because they knew that our competences included. . . the issuing of passports'. He recalled in particular the case of an elderly woman, whose husband had suffered an accident in France. When she went to the secret police headquarters for support, the PIDE allegedly issued a special passport in her name and even bought a train ticket for her so that she could visit her husband in hospital. ${ }^{49}$ Such generosity from the PIDE, if it existed at all, would have been limited to a few exceptional cases. Oscar Cardoso's excessively rosecoloured recollections notwithstanding, there is little doubt that the nature of the interactions that developed in these years between illegal migrants and the PIDE was not limited merely to the relation between repressor and persecuted.

\section{The PIDE as Instrument of Private Conflict Resolution}

The PIDE was not only approached to threaten coercive influence, and in many cases, individual citizens wanted to ensure that its repressive powers would be unleashed against a third party. Amongst the collection of letters assembled from the archives, there were sixteen cases where the authors of the denunciation letters approached the PIDE as an institution that could be enticed 'from below' into acting as an instrument of private conflict resolution. ${ }^{50}$ This figure suggests that the pursuit of a personal agenda could have been one of the principal - and perhaps overriding - motives behind the denunciations. This idea was initially put forward by Nuno Vasco in a work produced in the immediate aftermath of the Carnation Revolution, using fragmentary sources from the PIDE archives. ${ }^{51}$ It has since been taken up in the related literature, and is not particular to the Portuguese case. Whether in fascist Italy, Nazi Germany, Soviet Russia or socialist East Germany, scholarly research on denunciatory practices has emphasised the importance of personal motive in matters of denunciation, often linked to trivial inter-individual conflicts. ${ }^{52}$ In Würzburg, one man was denounced to the Gestapo by his father-in-law, 'allegedly for listening to foreign radio, but in reality because of domestic conflicts'. ${ }^{53}$ Another typical example of the 'personal agenda' letter in Soviet Russia was the 'apartment' denunciation, that is, 'the denunciation of neighbour by neighbour, often motivated by the desire to increase living space' in the so-called 'communal' apartments. ${ }^{54}$ In Salazar's Portugal as elsewhere, the nature of these private conflicts would vary greatly.

A range of private incidents and emotions could trigger a revenge denunciation. Upon being refused entrance to the 'Diana-Bar' for the carnival celebrations in Póvoa de Varzim, one citizen wrote to the PIDE asking them to investigate the 'suspicious' behaviour of the 'tall, skinny, bespectacled lad' from the local 'carnival ball commission'. Upon investigation the PIDE found that the suspect in fact belonged to a wealthy local family known to be supportive of the regime and that he had

48 PIDE, Del. P., vol. 82, NT9487, $10^{\circ}$ Livro, entry no. 1892.

49 In Bruno Oliveira Santos, Histórias Secretas da PIDE/DGS (Lisbon: Nova Arrancada, 2000), 50.

50 The total number of 'personal agenda' letters was probably higher. The figure given here includes only the cases whose origin could be traced unequivocally to the resolution of a private conflict.

51 Nuno Vasco, Vigiados e Perseguidos: Documentos Secretos da PIDE/DGS (Amadora: Bertrand, 1977), 39-41. From a journalistic perspective, see also 'Mais um Susbsídio Para o Dossier PIDE', Sempre Fixe, 10 Aug. 1974, 4; 'A PIDE e os seus Sinistros Métodos de Recolha de Informações', Diário Popular, 7 Feb. 1975, 8-9.

52 See Sheila Fitzpatrick, 'Signals From Below: Soviet Letters of Denunciation of the 1930s', The National Council for Soviet and East European Research: The Practice of Denunciation in Stalinist Russia, 1 (1994), 19-21; Carsten Dams and Michael Stolle, The Gestapo: Power and Terror in the Third Reich (Oxford: Oxford University Press, 2014), 72; Eric J. Johnson, Nazi Terror: the Gestapo, Jews, and Ordinary Germans (New York: Basic Books, 2000), 372-3; Gellately, 'Denunciations in Twentieth-Century Germany', 945; Mike Dennis, The Stasi: Myth and Reality (London: Pearson Longman, 2003), 95; Gieseke, History of the Stasi, 84.

53 Gellately, 'Denunciations in Twentieth Century Germany', 946.

54 Fitzpatrick, 'Signals From Below', 19. 
made 'many enemies' for his role as a doorman on carnival night. ${ }^{55}$ The PIDE was also used to settle disputes between neighbours. When it received an anonymous letter accusing Armando Alves, an employee of the Lello e Irmão typography in Porto, of distributing communist propaganda leaflets, the PIDE investigated and found the denunciation to be rooted in 'petty squabbles' with neighbours over 'a garden wall'. Jealousy among the neighbours, triggered by Alves' personal success, was also identified by the PIDE as a possible motive for the denunciation. ${ }^{56}$ Several other cases showed that individual citizens sought to entice the PIDE to act against a third party as a means of assuaging their material jealousy. The author of the anonymous 9 March 1964 denunciation of Augusto Dolores, a grocery store owner in Santa Marta de Penaguião, accused him of allegedly speaking 'against Dr. Oliveira Salazar'. He could not resist pointing out that Dolores had won a large sum of money 'at the Saint Anthony lottery', and that he 'now th[ought] of himself as the king of Santa Marta'. 57

The PIDE was also mobilised 'from below' in the context of family feuds, usually to actuate some form of emotional revenge. In Baixa da Banheira, Amândio dos Santos denounced his wife to the authorities after she left him to join the communist underground movement, eventually leading to her arrest by the PIDE on 13 September $1964 .{ }^{58}$ The archival material also includes three letters sent to the PIDE by feuding spouses in the context of a marital break-up. In one of them M. Pinheiro asked the PIDE to 'prevent his wife Lucila . . . from leaving the country', after she had 'abandoned the family home. ${ }^{59}$ In another, Joaquim Morango called upon the PIDE to launch 'an inquiry' after his wife had 'left for France without his authorisation'. ${ }^{60}$ Wives also reported on their husbands. On 7 May 1964 Maria Lima wrote to the secret police to 'ask that her husband . . be prevented from leaving the country'. ${ }^{61}$ These examples suggest that such cases were limited to exceptional circumstances, such as the breakdown of a marital relationship. Even in regimes of high-intensity ideological mobilisation, such as Nazi Germany or Soviet Russia, Hannah Arendt's 'gloomy diagnosis of the complete atomisation of society under totalitarianism' had failed to materialise. ${ }^{62}$ Arguably, the resistance of close family ties in the face of external attempts to penetrate them was greater still in a system of conservative, low-intensity mobilisation such as the New State, where the family was mostly allowed to function as an autonomous intermediary body between the individual and the state.

Another letter shows that the PIDE was solicited as a means of damaging unwanted business competition and to protect established financial interests. The case took place in Angeiras, a small coastal town north of Porto. Its object was the economic exploitation of the local beach. When Alexandre Rodrigues, a seasonal resident in the town, installed a mechanical traction device to pull the fishing boats up the beach (charging the fishermen a fee for the service), he met with the opposition of several local personalities. At first both sides traded accusations locally. Then, on 6 March 1964, the PIDE received an anonymous letter of denunciation, in which the author accused Júlio Pereira and Rodolfo Mesquita (two of the local personalities) of plotting to bring down 'Salazar's Government'. The PIDE investigated and found the accusations to be unfounded. The letter had in fact been written by Alexandre Rodrigues himself, as a form of retaliation against his detractors. Ultimately, the PIDE

\footnotetext{
55 PIDE, Del. P., P. Ind. 34172, NT 3979, letter received by the PIDE on 11 Feb. 1964, 2-6.

56 Apart from his professional ascension, Armando Alves had been allocated a low rent apartment by the Ministry of Corporations under a scheme that would eventually give him full ownership of the property, PIDE, Del. P., P. Ind. 10502, NT3618, letter received by the PIDE on 27 Jan. 1964, 1-6.

57 PIDE, Del. P., P. Ind. 34531, NT3985, letter received by the PIDE on 9 Mar. 1964, 3-6. Jealousy was also discernible as a motive in many of the letters written to denounce the individuals engaged in the lucrative clandestine emigration networks. One example was the letter sent to the PIDE on 18 August 1964 by Francisco Alves, from Caminha, in which he denounced João Valadares for unduly 'filling up with money' in his role as a people smuggler, PIDE, Del. P., PC 154/64, NT3211, 4.

58 PIDE, SC, PC 1015/64, NT5646, 35, 46 and 92.

59 PIDE, Del. P., vol 82, NT9487, 10 Livro, entry no. 2020, 12 Sept. 1964.

60 PIDE, Del. P., vol 82, NT9487, 10 Livro, entry no. 196, 1 Feb. 1964.

61 PIDE, Del. P., vol 82, NT9487, $10^{\circ}$ Livro, entry no. 886.

62 Gieseke, History of the Stasi, 88.
} 
ascribed the case to 'the clash of financial interests between all of the involved' - Rodolfo Mesquita, in particular, proving determined to protect his own business interests on the beach. ${ }^{63}$

Two of the denunciation letters also indicate that the PIDE was resorted to as a means of solving problems in the workplace. In the first, the author, who claimed to be the parent of a pupil at a catholic boarding school in Matosinhos (the Boa Nova college), accused Maria Oliveira, a former teacher at the school, of having used her position 'to inoculate [pupils] with the communist venom'. Again, the PIDE investigated the case and found the accusations to be unfounded. One of the pupils, whom the author of the letter had also accused of communist sympathies, was actually found to be the daughter of 'a leader of the Portuguese Youth' and 'very patriotic in character' ${ }^{64}$ Instead, the PIDE appeared to locate the origin of the denunciation in the resentment of Maria Oliveira's substitute at the school, Dora Vilhena, whose strict, conservative pedagogical methods had led to several complaints by the pupils and eventually to her dismissal. Her letter to the PIDE was probably designed as a form of retribution against her 'progressively-minded' predecessor and the pupils who had engineered her dismissal. The second anonymous letter, received on 3 January 1964, also came from an individual claiming to be the parent of a school pupil, this time at the seminary in Ermesinde. In it the author reported upon alleged 'subversive activities' among the teachers, singling out Father Sebastião Bras as 'particularly suspicious'. After a 'discreet investigation' the PIDE discovered that the denunciation in fact originated from an earlier disagreement between the priest and two teachers at the seminary after which the latter had been dismissed. At the time of the dispute, one of these teachers, Manuel Barbosa, had 'even got to the point of telling several. . .employees at the school that he would write to the PIDE to ruin Father Sebastião's life by branding him a communist'. ${ }^{65}$ The fact that Manuel Barbosa should have so openly declared his intention to write to the PIDE in order to discredit the priest suggests that the culture of instrumental denunciation had become a common occurrence in Salazar's Portugal.

Overall, the small but important collection of letters shows that the PIDE was activated from below out of feelings of revenge, envy and resentment, to settle family feuds, damage business competition and solve problems at the workplace and, in doing so, reveals the importance of personal motives in the activation of the denunciations. However, allocating the origin of the denunciations to a single motive would be reductive. Self-interest, no matter how important it may have been, was often insufficient to explain the denunciations. According to the collection of letters, these tended rather to result from a complex cluster of mutually reinforcing motives, which often included a diffuse sense of identification with the incumbent regime.

\section{The PIDE as Platform for Collaborative Interaction with the Regime}

There has been very little research into the image that the PIDE tried to project of itself domestically and on its potential channels of interrelation with society. ${ }^{66}$ The evidence available to historians shows that 'bottom-up' collaboration with the PIDE was sometimes directly encouraged by the authorities. On 17 February 1970, in the context of a nationwide campaign against pornography, the Ministry of the Interior published an official note in the national press calling upon all citizens to contribute to the campaign by sending their 'complaints' (i.e. denunciations) to the secret police. ${ }^{67}$ The case showed that the ideological values embodied by the regime could sometimes provide a platform for collaboration between individual citizens and the public authorities, including the secret police,

63 PIDE, Del P., P. Ind. 30967, NT 3932, 7-10. In February 1966 the case gave rise to a second anonymous letter, in which, by a process of symmetrical inversion, Alexandre Rodrigues himself was accused of being a communist. The PIDE took the letter to constitute Júlio Pereira and Rodolfo Mesquita's belated 'response' to the accusations earlier levelled against them, PIDE/DGS, Del P., P. Ind. 30967, NT 3932, letter dated 6 Feb. 1966, 6.

64 PIDE, Del. P., P. Ind. 34015, NT3977, letter received by the PIDE on 2 Jan. 1964, 2-8.

65 PIDE, Del. P., P. Ind. 18962, NT3755, 11-15.

66 Pimentel's vast history of the PIDE devotes only two pages to the issue, presented essentially as an exercise in 'public relations', A História da PIDE, 303-5.

67 In Simpson, 'Letters of Denunciation', 17. 
whose task it was to eliminate any sign of deviance from the norm. In effect, the rationalised statement of the PIDE's mission offered the opportunity for common citizens to contribute towards its realisation out of a shared engagement to uphold some of the values defended by the regime.

The archives point to the existence of 'duty denunciations' - those made exclusively out of a sense of ideological commitment to the regime ${ }^{68}$ - in Salazar's Portugal. Indeed fifteen of the eighty-four letters of denunciation (including those found in the correspondence registers) were written explicitly to denounce communist sympathisers. A further ten letters were written to report on suspected 'antisituationists', an all-encompassing term that covered a wide range of pro-democratic political currents (from republicans to socialists) but could also include communists. This suggests that society did not remain immune to the New State's much-propagated discourse on the evils of communism. Out of these twenty-five letters encountered primarily in the correspondence registers of the Ministry of the Interior (which duly forwarded them to the PIDE), only three could be located in the archives. This means that our insight into the nature of the discourse articulated by the denouncers remains limited, and that any attempt to interpret them must be done tentatively. Still, they provide valuable clues into the practice of 'duty denunciations'.

All three letters were written to report on the 'subversive' activities of António Jorge and Jerónimo Bernardes in the small town of Alpiarça, in the Ribatejo. In terms of content, they were notable for the virulence of their diatribes against communism, perceived as a disruptive ideology corrupting the natural order and bringing shame not only on its sympathisers but on the whole of the communities 'infected' even if only partly - by it. In his letters to the Minister of the Interior, Alfredo dos Santos Júnior, dated 14 and 19 May 1964, Rufino Sebastião worried that Alpiarça may be 'completely lost'. Consequently he called upon the PIDE to intervene 'for the good of the nation', by 'punishing those communists who in such a small town are doing so much harm to our beloved fatherland ${ }^{69}$ In the third, anonymous letter, sent to the PIDE on 6 July 1964, the author referred to communism as 'that cursed doctrine', calling for Jerónimo Bernardes, whose 'backward communist life' had given the town a 'bad reputation', to be 'locked up in a cell'. The long enumeration of his crimes included the blasphemous decision to 'name his dog Salazar. ${ }^{70}$ This type of discourse suggests that the letters were written out of a genuine feeling of identification with New State anti-communism, and that they were possibly induced by a sense of duty to partake in the effort to protect the nation from the negative effects of communist infiltration. The fact that both António Jorge and Jerónimo Bernardes were arrested by the PIDE showed that the denunciations were founded and that the secret police had taken them seriously.

The fact that several of the denunciation letters explicitly referred to the ideology of the regime suggests that their authors were approaching the PIDE in a spirit of programme-based collaboration with the New State. In this case too, however, any interpretation must be done provisionally, not only because of the size of the sample, but also because of the possible tendency of the authors of the letters to couch them in terms designed to ensure that the PIDE would act quickly.

Two of Salazarism's fundamental tenets were invoked with particular frequency. The first was the commitment to Catholicism as the natural spiritual framework of the nation. In a society subjected to the effects of the alliance between the New State and the Catholic Church, aimed at achieving an idealised (and failed) programme to 're-Christianise' the nation, ${ }^{71}$ conservative Catholic principles of morality permeated the established moral norms. These frequently appeared in the denunciation letters. Eighteen letters in the sample (including the correspondence registers) were written to report on individuals suspected of engaging in 'disreputable' activities, such as gambling and prostitution, and can be seen partly in light of the Estado Novo's own campaign for the defence of 'moral virtue and decency.. ${ }^{72}$

\footnotetext{
68 Such as denouncing signals of political disloyalty, ideological impurity or 'class enemies' in Soviet Russia, Fitzpatrick, 'Signals from Below', 5-13.

69 PIDE, SC/E/GT 649, NT 1444, 8-10.

70 PIDE, SC, PC 1728/64, NT5691, 24-26.

71 Duncan Simpson, A Igreja Católica e o Estado Novo Salazarista (Lisbon: Edições 70, 2014).

72 As a matter of public order rather than a political crime per se, they were dealt with not by the PIDE but by the GNR or the Polícia de Segurança Pública (PSP), the regular policing entities responsible for policing rural and urban areas
} 
Three more of the denunciation letters were written by catholic priests. In the first, Father Manuel Castinho, the parish priest in Vila Nova de Foz Coa, reported on the circulation of 'pornographic photos' and a local 'campaign against the Church'. ${ }^{73}$ In the second, Father Serafim Lara denounced a primary school teacher for 'preventing [him] from teaching the Morals classes, ${ }^{74}$ In the third, Father João da Silva, the parish priest in Folgosa do Douro, reported on the 'scandalous' lifestyle of one of his (female) parishioners. ${ }^{75}$ All three letters were written out of a sense of shared duty with the public authorities to preserve the nation's spiritual well-being, highlighting the role frequently played by provincial clergy as 'agents of social conformity and political vigilance'. ${ }^{76}$

The second frequently invoked principle of New State ideology was colonialism. Salazar's discourse on the specificities of Portugal's imperial projection overseas, and its importance for the nation, had acquired a particular significance in the context of the colonial war. Many of the denunciation letters relating to illegal emigration echoed this discourse by emphasising the need to clamp down on the clandestine networks in order to prevent able-bodied young men from evading their patriotic duty in 'Portuguese Africa'. In the letter he wrote to the PIDE on 18 August 1964 to denounce João Valadares for his role in the passage to France of fifty illegal migrants, Francisco Alves insisted on the gravity of the offence by reporting that 'many [of them] were about to begin their military service. ${ }^{77}$ In the mid-1960s the attachment to the nation's colonial territories remained a popular though far from universal - feeling in Portugal. In a report to his superiors in August 1964, one PIDE agent in Guarda noted that the most frequently heard complaint among the local population was the fact that 'while some send several of their children to defend the Overseas Territories, many others only follow the path to France'. ${ }^{78}$ In Ponte de Sor, where the PIDE had placed Father Joaquim Pinto de Andrade (an Angolan priest in favour of independence) under house arrest, the local population promptly mobilised to obtain his removal from the town, referring to him as a 'traitor to the Fatherland'. ${ }^{79}$ Opinion surveys carried out after the downfall of the regime would later show that the Estado Novo's colonial policies, which allowed the regime to generate a measure of renewed political consensus after the outbreak of war, had found a particular echo among the more modest, uneducated social groups. ${ }^{80}$ The references frequently made to the 'overseas provinces' in the denunciation letters partly reflected this feeling.

In a regime of low-intensity ideological mobilisation offering the population no participatory equivalent to Nazi Germany's Volksgemeinschaft or East Germany's socialist utopia, the propensity of denunciations to originate from a mere sense of duty was proportionally limited, however. As the letters show, the affirmation of duty tended instead to coexist with other discernible motives, usually the pursuit of a personal agenda. As we have seen, Francisco Alves's denunciation of João Valadares as a passador was rooted both in a sense of identification with the preservation of 'Portuguese Africa' and financial jealousy. ${ }^{81}$ Similarly, Francisco Ribeiro's denunciation letter, written

respectively. One example was the letter sent by Viriato Melo on 16 April 1964, in which he demanded that 'measures be taken to close down the Pensão Braz for practising activities contrary to the law and to morality', Ministério do Interior, Gabinete do Ministro (inc. 2003), Registo de Correspondência Recebida, 1964, NT35, entry no. 3215.

73 Ministério do Interior, Gabinete do Ministro (inc. 2003), Registo de Correspondência Recebida, 1964, NT36, entry no. 8993, 4 Nov. 1964.

74 Ministério do Interior, Gabinete do Ministro (inc. 2003), Registo de Correspondência Recebida, 1964, NT34, entry no. 1684, 18 Feb. 1964.

75 Ministério do Interior, Gabinete do Ministro (inc. 2003), Registo de Correspondência Recebida, 1964, NT35, entry no. 5256, 30 June 1964. The parish priest of Atalaia (Pinhel) also forwarded an oppositionist pamphlet to the PIDE post in Guarda for investigation, PIDE, Del. C., Proc. s/nº, NT10713, internal report dated 13 Apr. 1964, 88.

76 Tom Gallagher, 'Controlled Repression in Salazar's Portugal', Journal of Contemporary History, 14, 3 (1979), 397.

77 PIDE, Del. P., PC 154/64, NT3211, 4.

78 PIDE, SC, SR 1330/64, NT3403, report dated 24 Aug. 1964, 5.

79 PIDE, SC, PC 1759/64, NT5694, Jan. 1964, 2 and 8.

80 In Rui Ramos, “'O Império que Nunca Existiu”: a Cultura da Descolonização em Portugal C. 1960-C.1980', Revista de História das Ideias, 28 (2007), 443.

81 PIDE, Del. P., PC 154/64, NT3211, 4 
to denounce José Contente as a people smuggler, included both a long, morally-imbued digression into the 'dissolute' private lives of the suspect and his relatives - indicating a sense of identification with the conservative principles upheld by the Salazar regime - and evidence of having been written out of a sense of material envy and personal resentment. ${ }^{82}$ In each of these cases - of which the sample contains many more -, the denouncers' overriding motive appears to have been the pursuit of a personal agenda. But they were also evidently in sufficient agreement with some aspects of Salazarism not to consider their actions reprehensible from a political or moral standpoint, which in turn contributed to lowering the inhibition threshold of denunciation. ${ }^{83}$

\section{The PIDE as a Source of Economic Opportunity}

According to the Commission for the Extinction of the PIDE/DGS, the PIDE operated a network of approximately 20,000 paid informers in $1974 .^{84}$ Regular informers were paid a monthly salary, whereas the smaller 'occasional collaborators' were remunerated according to the quality of the information provided. ${ }^{85}$ One case in the archives reflects the importance of this network for the secret police. It concerned the arrest of the communist militant Aureliano dos Santos for his role in the demonstrations of 1 May 1964, in Lisbon. Shot and wounded by the police during the unrest, he had managed to escape from the scene and make his way home by taxi, without being spotted. The PIDE only caught on to him because one of its paid informers, Ulisses Godinho, witnessed the scene, jotted down the taxi's number plate and reported it to his 'controller' in the secret police, Sub-inspector Baptista da Silva ${ }^{86}$ Although as a norm the PIDE pro-actively sought out its informers, members of the public could also spontaneously 'apply' for the role. The archives, albeit limited in number, nevertheless provide unique insight into the phenomenon of 'spontaneous application letters' to the PIDE.

Correspondence registers of the ministry of the Interior in 1964 show that it received twenty-three 'spontaneous application letters' from citizens interested in joining the PSP, and seventeen from those wishing to enter the GNR. ${ }^{87}$ Over the same period of time, it received eighty-one such letters from individuals wanting to join the PIDE, either as an informer (twenty-one) or as a full-time functionary (sixty). ${ }^{88}$ The correspondence register contains short summaries of these letters, allowing us to gain some insight into the nature of this correspondence. Many of these applicants came from the lower socio-economic classes, it would seem, because of the nature of the roles chosen by the prospective candidates as their preferred position in the secret police. António Nunes and Júlio Nogueira, in letters dated 20 March and 27 June 1964, respectively, enquired about 'a place in the PIDE as a driver'. ${ }^{89}$ On 25 August 1964 António Cristovão 'ask[ed] for a position as a car cleaner in the PIDE's garage'. ${ }^{90}$ Rosa Ferreira also wrote to request 'a place in the PIDE's cleaning services'. ${ }^{91}$ Additional evidence, gathered from a further sample of application letters written to the PIDE by individual citizens between 1963

\footnotetext{
82 PIDE, Del. C., Proc. 553, NT10690, letter dated 12 Jan. 1964, 951.

83 Here I adapt a formulation used by Gieseke, History of the Stasi, 84.

84 In Pimentel, História da PIDE, 315. In November 1969 the PIDE was renamed Direcção-Geral de Segurança (DGS), also for cosmetic reasons, during the short period of liberalisation that followed Salazar's exit from the political stage (the so-called 'Marcellist Spring').

85 Pimentel, História da PIDE, 318

86 PIDE, SC, PC 1750/64, NT5693, 4 and 45

87 Ministério do Interior, Gabinete do Ministro (inc. 2003), Registo de Correspondência Recebida, 1964, NT34-35-36.

88 Ministério do Interior, Gabinete do Ministro (inc. 2003), Registo de Correspondência Recebida, 1964, NT34-35-36.

89 Ministério do Interior, Gabinete do Ministro (inc. 2003), Registo de Correspondência Recebida, 1964, NT35, entries no. 2263 and 5568.

90 Ministério do Interior, Gabinete do Ministro (inc. 2003), Registo de Correspondência Recebida, 1964, NT36, entry no. 7240.

91 Ministério do Interior, Gabinete do Ministro (inc. 2003), Registo de Correspondência Recebida, 1964, NT34, entry no. 1345, letter dated 13 Feb. 1964.
} 
and $1965,{ }^{92}$ confirms this impression, not only because of the poor quality of the syntax and lexical range displayed by the authors (a sign of their low cultural capital and socio-economic status), but also because the applicants themselves did not hesitate to put forward their destitute material situation as part of their pleas for a position in the PIDE. Thus one applicant referred to himself as a 'poor illiterate fellow' (pequeno a Nalfabético [sic])..$^{93}$

The fact that the PIDE recruited primarily from the lower strata of society has been emphasised before. ${ }^{94}$ Traditionally, however, it has been interpreted as a sign of the 'uncivilised' nature of the PIDE as a police entity, rather than as evidence of its potential role as an economic resource for individual citizens affected by poverty. As has been observed in relation to other societies subjected to dictatorial control, popular attitudes towards official institutions were often driven by what they could provide in terms of 'opportunities for control over material goods, career advancement, or social promotion'. ${ }^{95}$ Such pragmatism arguably intensified in proportion to the degree of material deprivation of the individuals approaching the official institutions. The need for social promotion in particular can perhaps help to explain the PIDE's apparent comparative advantage as a potential employer relatively to the GNR and PSP, as suggested by the number of spontaneous application letters received by the Ministry of the Interior in relation to each of these police entities. It would be wrong, of course, to assume that all of the PIDE's voluntary applicants were poverty-stricken. One applicant enquired about a position as a dactylographer, another as a radio-telegraphist, ${ }^{96}$ signalling a measure of education and training. It would also be speculative to assess the importance of the phenomenon on the face of the research carried out for the present article. What the empirical evidence uncovered so far does strongly suggest, however, is that the realities of widespread poverty in Salazar's Portugal played some part in fashioning the relation between society and the PIDE, the exact importance of which is still to be determined.

\section{Conclusion}

This article has shown the multi-faceted nature of the relations between society and the PIDE. In doing so it has sought to nuance and complement the current historiographical focus on top-down mechanisms of repression. The archives from 1964 show that individual citizens spontaneously resorted to the PIDE as an influential sponsor, an appropriable coercive device, an instrument of private conflict resolution, a platform for collaboration with the regime and an economic resource. Arguably, the PIDE's growing difficulty in carrying out its mission by the mid-1960s may have played a part in promoting different attitudes towards it among the population, in particular as regards the question of illegal emigration.

Three aspects of the ways in which the PIDE was approached 'from below' deserve to be highlighted. First, the diversity of the motives behind the appeals made to the PIDE by individual citizens suggests a high degree of normalisation of the New State's institutional set-up as the framework for daily life in Salazar's Portugal. The phenomenon was not specific to the New State and has been observed in other high-longevity regimes, such as Soviet Russia or East Germany. ${ }^{97}$ Rather than remaining passive, society adapted to the institutional framework imposed by the dictatorship, including its secret police. Individual citizens exploited the opportunities that presented themselves, either as a means of bypassing the blockages typical of a non-inclusive political system (through petitions or application letters) or to further a personal agenda (through denunciations). Such signals of normalisation 'from below' must be taken into consideration when trying to account for the longevity of the regime, as much as the well-studied mechanisms of top-down repression exercised by the PIDE.

\footnotetext{
92 Simpson, 'Letters of Denunciation', 21-3.

93 Ibid., 22-3.

94 Pimentel, História da PIDE, 56.

95 On the case of fascist Italy, see Paul Corner, 'Collaboration, Complicity, and Evasion under Italian Fascism', in Lüdtke, ed., Everyday Life in Mass Dictatorship, 77.

96 Ministério do Interior, Gabinete do Ministro (inc. 2003), Registo de Correspondência Recebida, 1964, NT35, entries no. 3689 and 4038, letters dated 3 May 1964 and 18 May 1964 respectively.

97 For a discussion of the 'normalisation of rule' in East Germany, see Mary Fulbrook, ed., Power and Society in the GDR, 1961-1979 (Oxford: Berghahn Books, 2009).
} 
Second, although the so-called 'duty denunciations' certainly existed under the Salazar regime, they were probably less frequent than in the regimes of high-intensity ideological mobilisation. The New State offered its citizens the opportunity to partake in the realisation of its ideological programme but not, for example, on a scale equivalent to participation in the Nazi Volksgemeinschaft or East Germany's socialist utopia. According to the sample, denunciations tended rather to result from a cluster of motives, often blending a sense of support for the regime (or for one aspect of its ideology) with the opportunistic pursuit of a personal agenda. Finally, the letters of 'spontaneous application' to join the PIDE suggest that, in a context marked by deeply-ingrained social inequalities and widespread poverty, material deprivation also played a part in shaping the nature of the relation between society and the PIDE.

In terms of policing, 'bottom-up' interactions such as the letters of denunciation written by unsolicited citizens provided the PIDE with the means to penetrate social relations at the local, even interindividual, level. To use a Foucauldian concept, they were part of the New State's 'capillary operation of power'. As such, they also contributed towards the regime's exceptional durability. In a broader perspective, the archival sample also provides some insight into the way power itself was conceived of and exercised by the authorities of the New State. It is indeed noticeable that in many of the individual cases in the archival sample the PIDE was approached 'from below' by citizens eager to use its status as a core institution in the regime to put forward a personal request for attention. Often out of material necessity, individual citizens were effectively 'drawn into' collaboration with the PIDE, whether as a means of overcoming bureaucratic indifference (such as through the petitioning of a PIDE official in A-da-Beja), of putting forward an appeal for some form of particularistic treatment which only the PIDE could provide (such as to obtain the restitution of a 'fee' from a smuggler or to trace a relative abroad) or simply of gaining access to a source of income (as ultimately exemplified by the spontaneous applications to join the PIDE). The PIDE's responsiveness in turn stimulated the development of instrumental relations between itself and society, reinforcing its role as an institution whose agents could be resorted to 'from below' to dispense personal favours or services.

The relationship between the PIDE and the citizens who spontaneously interacted with it, as it emerges from the collection of letters, shares some similarities with the social processes studied by scholars of clientelism as a system of social control. ${ }^{98}$ This is particularly obvious from the 'client side' of the relationship, in other words the survival strategies of compliance or collaboration adopted by subaltern social groups to gain access to resources or to influence decision making in the context of a non-inclusive political system. Resorting to the concept of clientelism as an analytical framework also helps to open up new questions about the nature of the 'everyday' interactions between individual citizens and the PIDE. One particular area of study concerns the extent to which the PIDE's responsiveness to personalised requests might have formed part of a broader system of governance, transversal to the regime's institutions, in which the use of discretionary power by the agents of authority served as a purposeful means of keeping the population under their control. Further research will be needed, however, in order to determine the applicability of such an interpretative model to the Salazarist New State.

Acknowledgements. Part of the work on this article was carried out as the recipient of a Marie Curie Individual Fellowship (Grant ID: 842320). I am grateful to the anonymous reviewers and to the journal's editorial team, in particular Ludivine Broch, for their helpful comments and feedback.

\footnotetext{
98 On Peronist clientelism in Argentina, see the works of the political ethnographer Javier Auyero, in particular 'The Logic of Clientelism in Argentina: an Ethnographic Account', Latin American Research Review, 35, 3 (2000), 55-81; Poor People's Politics (Durham, N.C.: Duke University Press, 2001) and 'Poor People's Lives and Politics: The Things a Political Ethnographer Knows (and Doesn't Know) After 15 Years of Fieldwork', New Perspectives on Turkey, 46 (2012), 95-127.
}

Cite this article: Simpson D (2020). Approaching the PIDE 'From Below': Petitions, Spontaneous Applications and Denunciation Letters to Salazar's Secret Police in 1964. Contemporary European History 1-16. https://doi.org/10.1017/ S0960777320000612 